\title{
Performance evaluation of $\mathrm{HBsAg}$ by Lumipulse $\mathrm{HBsAg}-\mathrm{HQ}$ : The agreement with $\mathrm{HBsAg}$ by Architect HBsAg-QT and the effectiveness in predicting liver tissue pathological states of chronic hepatitis B patients
}

\author{
Zhanqing Zhang ${ }^{1, A, C, D, F, \text { Rongrong Ding }}{ }^{1, B, D}$, Wei Lu ${ }^{1, B, E}$, Zhiqiang Yang ${ }^{2, E}$, \\ Yanbing Wang ${ }^{1, B}$, Xinlan Zhou ${ }^{1, B}$, Dan Huang ${ }^{1, B}$, Xiufen Li ${ }^{1, B}$, Yanling Feng ${ }^{1, B}$ \\ 1 Shanghai Public Health Clinical Center, Fudan University, China \\ ${ }^{2}$ Fujirebio Shanghai Representative Office, China \\ A - research concept and design; $\mathrm{B}$ - collection and/or assembly of data; $\mathrm{C}$ - data analysis and interpretation; \\ $D$ - writing the article; $E$ - critical revision of the article; $F$ - final approval of the article
}

Address for correspondence

Zhanging Zhang

E-mail: doctorzzqsphc@163.com

\section{Funding sources}

This work was supported by the "The Twelfth Five-Year" National Science and Technology Key Projects of China (№. 2013ZX10002005), and the key scientific research project of Shanghai Municipal Health and Family Planning Commission of China (№. 20134032).

Conflict of interest

None declared

\section{Acknowledgements}

The Lumipulse HBsAg kits were kindly provided by Fujirebio Shanghai Representative Office.

Received on October 28, 2016 Reviewed on January 29, 2017 Accepted on March 1, 2017

DOI

10.17219/acem/69247

\section{Copyright}

Copyright by Author(s)

This is an article distributed under the terms of the

Creative Commons Attribution Non-Commercial License

(http://creativecommons.org/licenses/by-nc-nd/4.0/)

\begin{abstract}
Background. A novel high-sensitivity HBsAg quantification assay, Lumipulse $\mathrm{HBsAg-HQ}$, was developed. However, its performance in practical application has not yet been adequately investigated.

Objectives. The aim of the study was to evaluate the agreement of serum HBsAg by Lumipulse HBsAg-HQ ( $\mathrm{HBsAg}-\mathrm{HQ}$ ) with HBsAg by Architect HBsAg-QT (HBsAg-OT) and comparatively investigate the efficacy of serum $\mathrm{HBsAg}-\mathrm{HQ}$ and $\mathrm{HBsAg}-\mathrm{QT}$ in predicting the liver tissue pathological states of chronic hepatitis $B(\mathrm{CHB})$ patients.
\end{abstract}

Material and methods. A total of $147 \mathrm{HBeAg}$-positive and $128 \mathrm{HBeAg}$-negative patients were enrolled. HBsAg-HQ and HBsAg-QT were measured using CLEIA Lumipulse G1200 and CMIA Abbott Architect I2000 automatic analyzer, respectively. The Scheuer standard was used for the pathological diagnosis of liver tissue samples.

Results. In both HBeAg-positive and HBeAg-negative patients, $\mathrm{HBsAg-HQ}$ was significantly positively correlated with HBsAg-QT ( $r=0.913$ and $r=0.959$, respectively), the overall disagreement rates between $\mathrm{HBsAg}-\mathrm{HQ}$ and $\mathrm{HBsAg}-\mathrm{QT}$ were $2.72 \%$ (4/147) and 4.69\% (6/128), respectively. In HBeAg-positive patients, the area under the ROC curve (AUC) of $\mathrm{HBsAg}-\mathrm{HQ}$ and $\mathrm{HBsAg}-\mathrm{QT}$ for predicting the grade $\geq \mathrm{G3}$ (0.686 and 0.684 , respectively) and stage $\geq S 4$ ( 0.739 and 0.745 , respectively) were the greatest compared with other pathological states; the optimal cutoffs of $\mathrm{HBsAg}-\mathrm{HQ}$ and $\mathrm{HBsAg}-\mathrm{QT}$ for predicting the grade $\geq \mathrm{G3}$ were $<2.244 \times 10^{7} \mathrm{mlU} / \mathrm{mL}$ and $<3.589 \times 10^{7} \mathrm{mlU} / \mathrm{mL}$, and those for predicting the stage $\geq S 4$ were $7.328 \times 10^{6} \mathrm{mlU} / \mathrm{mL}$ and $<6.194 \times 10^{6} \mathrm{mU} / \mathrm{mL}$, respectively.

Conclusions. $\mathrm{HBsAg}-\mathrm{HQ}$ is highly correlated and in agreement with $\mathrm{HBsAg}-\mathrm{QT}$ in both $\mathrm{HBeAg}-$ positive and $\mathrm{HBeAg}$-negative patients; $\mathrm{HBsAg-} \mathrm{HQ}$ and $\mathrm{HBsAg}-\mathrm{QT}$ are very valuable in predicting the grade $\geq \mathrm{G} 3$ and stage $\geq S 4$ in HBeAg-positive patients.

Key words: hepatitis B surface antigen, performance evaluation, Lumipulse $\mathrm{HBs} A g-\mathrm{HQ}$, pathology, noninvasive diagnosis 


\section{Introduction}

The detection of serum hepatitis B surface antigen (HBsAg) is the leading hallmark for screening and diagnosing hepatitis B virus (HBV) infection. In the past 10 years, serum HBsAg quantification assays have been developing rapidly. Among them, Architect HBsAg-QT (Abbott Laboratories, Chicago, USA) and Elecsys HBsAg II (Roche Diagnostics GmbH, Mannheim, Germany) have been widely studied and preliminary applied..$^{1-4}$ Several studies have demonstrated that the levels of serum HBsAg are different during the various phases of natural history and are associated with the liver tissue pathological states of chronic HBV infection. ${ }^{5-8}$ Furthermore, some evidence has reinforced its value in predicting drug efficacy and evaluating the prognosis in patients with chronic hepatitis $\mathrm{B}(\mathrm{CHB}){ }^{9,10}$

Recently, a novel high-sensitivity linearized HBsAg quantification assay, Lumipulse HBsAg-HQ (Fujirebio Inc., Tokyo, Japan), was developed. ${ }^{11}$ The original studies on this assay indicated that the detection of serum HBsAg by Lumipulse HBsAg-HQ (HBsAg-HQ) could potentially assist in diagnosing occult hepatitis $B$ infection ${ }^{12-15}$ and showed consistent results with the qualitative and quantitative detection of serum HBsAg by Architect HBsAg-QT (HBsAg-QT) and HBsAg by Elecsys HBsAg II (HBsAg-E II). ${ }^{16,17}$ However, the correlation between the serum HBsAg-HQ levels and the natural history and the liver tissue pathological states of chronic HBV infection have not yet been adequately investigated. ${ }^{18}$

\section{Objectives}

The objective of this study is to further evaluate the agreement of serum HBsAg-HQ with HBsAg-QT and comparatively investigate the effectiveness of serum $\mathrm{HBsAg-HQ}$ and HBsAg-QT in predicting the liver tissue pathological states of $\mathrm{CHB}$ patients.

\section{Material and methods}

\section{Patients}

A total of 275 Chinese patients with chronic HBV infection who were hospitalized in the Shanghai Public Health Clinical Center of Fudan University (Shanghai, China) between August 2012 and July 2015 were prospectively enrolled, among whom 147 and 128 patients were hepatitis $\mathrm{B}$ e antigen (HBeAg)-positive and $\mathrm{HBeAg}$-negative, respectively. The diagnoses of all the patients were in accordance with the standards set forth in the Asian-Pacific clinical practice guidelines for the management of hepatitis $B$ (2015 update).${ }^{19}$ Patients with other forms of viral hepatitis, drug-induced liver injuries, hereditary liver diseases, schistosomiasis japonica infection, autoimmune diseases, endocrine and metabolic diseases, and blood system diseases were excluded. Patients who had been treated with interferon alpha, nucleosi(t)des, steroids, or licorices were also excluded.

All patients provided written consent prior to a liver biopsy, and all clinical investigations were conducted according to the principles expressed in the 1995 Declaration of Helsinki.

\section{Histological assessment}

Ultrasound-assisted liver biopsies were performed using a 1-second liver biopsy needle (16G). The biopsies were collected immediately after the procedure and transferred into plastic tubes for freezing. One pathologist, who was blinded to all biochemical, serologic and virological parameters, was assigned to review all biopsy specimens. A biopsy length of at least $10 \mathrm{~mm}$ was required for inclusion in this study. The pathological diagnosis of liver tissues was performed independently by 1 experienced pathologist. The pathological diagnosis referred to the Scheuer standard, ${ }^{20}$ in which a grade is used to describe the intensity of the necro-inflammatory activity, and a stage is used as a measure of fibrosis and architectural alteration. The grades include 5 levels, G0-G4, and the stages include 5 levels, $\mathrm{S} 0-\mathrm{S} 4$.

\section{Laboratory assays}

Serum samples used for measurements were taken within 1 week before and 1 week after liver biopsy and stored at $-40^{\circ} \mathrm{C}$. Serum HBsAg-HQ and HBsAg-QT were quantified using chemiluminescence enzyme immunoassay (CLEIA) in a Lumipulse G1200 automated analyzer (Fujirebio Inc., Tokyo, Japan) and chemiluminescence microparticle immunoassay (CMIA) in an Abbott Architect I2000 automated analyzer (Abbott Laboratories, Chicago, USA), respectively. The HBsAg-HQ reagents were provided by Fujirebio Inc., and the HBsAg-QT reagents were purchased from Abbott Laboratories. The linear detection range of the HBsAg-HQ was from 5 to $150000 \mathrm{mIU} / \mathrm{mL}$. If the serum exceeded the upper detection limit, it was diluted 1,000 times and remeasured. Similarly, the linear detection range of the HBsAg-QT was 50 to $250000 \mathrm{mIU} / \mathrm{mL}$, and if the serum exceeded the upper detection limit, it was diluted 500 times and remeasured.

The serum HBeAg was measured using CMIA Abbott Architect I2000 automated analyzer, with a lower detection limit of $1 \mathrm{~S} / \mathrm{CO}$. The serum HBV DNA was measured using Bio-Rad Icycler PCR System (Bio-Rad Laboratories, Inc., USA), and the polymerase chain reaction (PCR) kits were obtained from Qiagen Shenzhen Co. Ltd. (Shenzhen, China). The linear detection range of HBV DNA was $5 \times 10^{2} \mathrm{IU} / \mathrm{mL}$ to $5 \times 10^{7} \mathrm{IU} / \mathrm{mL}$. 


\section{Statistical analysis}

Statistical analyses were performed using MedCalc v. 15.1 (MedCalc Software, Broekstraat, Mariakerke, Belgium). A paired-samples t-test was used to compare the differences between the serum HBsAg-HQ and HBsAg-QT. Pearson correlation, linear regression analysis and BlandAltman plots were used to evaluate the agreement between the HBsAg-HQ and HBsAg-QT quantitation. Spearman's correlation analysis was used to analyze the correlation of the serum HBsAg-HQ and HBsAg-QT levels with the liver tissue pathological grade and stage. The receiver operating characteristic (ROC) curve was used to assess the effectiveness of serum HBsAg-HQ and HBsAg-QT for predicting the different liver tissue pathological states. The paired-samples DeLong non-parametric test was used to compare the differences in the area under the ROC curve (AUC) between the serum HBsAg-HQ and HBsAg-QT for predicting the same liver tissue pathological states. A 2-sided p-value of less than 0.05 was considered to be significant.

\section{Results}

\section{Clinical characteristics of the patients}

There was no significant difference in the male-to-female ratio $(\mathrm{p}=0.490)$ between the HBeAg-positive and HBeAg-negative patients; however, there was a significant difference in the average age $(p=0.000)$ between the $\mathrm{HBeAg}$-positive and HBeAg-negative patients. The difference in alanine transaminase (ALT) ( $p=0.947)$ between the $\mathrm{HBeAg}$-positive and $\mathrm{HBeAg-negative} \mathrm{patients} \mathrm{was}$ not statistically significant. The differences in the serum HBsAg-HQ, HBsAg-QT and HBV DNA (all p = 0.000) between the HBeAg-positive and HBeAg-negative patients were all statistically significant. There was a significant difference ( $p=0.046)$ in the frequency of the different pathological grades, but there was no significant difference $(p=0.469)$ in the frequency of the different pathological stages between the HBeAg-positive and HBeAg-negative patients (Table 1).
In the $\mathrm{HBeAg}$-positive patients, the serum HBsAg-HQ and HBsAg-QT had a significant negative correlation with the serum ALT $(r=-0.258 ; p=0.002$ and $r=-0.254$; $\mathrm{p}=0.002)$. In the HBeAg-negative patients, the serum HBsAg-HQ and HBsAg-QT did not have a significant correlation with the serum ALT $(r=-0.094 ; p=0.291$ and $\mathrm{r}=-0.067 ; \mathrm{p}=0.454$ ) (Fig. 1A-D). In both the HBeAgpositive and $\mathrm{HBeAg}$-negative patients, the serum HBsAgHQ and HBsAg-QT levels were significantly positively correlated with the serum HBV DNA $(r=0.524 ; \mathrm{p}=0.000$ and $\mathrm{r}=0.501 ; \mathrm{p}=0.000$ in the $\mathrm{HBeAg}$-positive patients, and $\mathrm{r}=0.350 ; \mathrm{p}=0.000$ and $\mathrm{r}=0.390 ; \mathrm{p}=0.000$ in the HBeAg-negative patients) (Fig. 2A-D).

\section{Comparison between $\mathrm{HBsAg}-\mathrm{HQ}$ and HBsAg-QT levels}

Regardless of serum HBeAg state and HBsAg levels, there was no significant difference between the serum HBsAg-HQ and HBsAg-QT ( $\mathrm{p}=0.691)$. Grouping the patients according to serum HBeAg state and HBsAg levels showed that there were no significant differences between serum HBsAg-HQ and HBsAg-QT in patients with both HBeAg-positive $(\mathrm{p}=0.853)$ and $\mathrm{HBeAg}$-negative $(\mathrm{p}=0.647)$ and in patients with both higher HBsAg levels (HBsAgQT $\geq 100000 \mathrm{mIU} / \mathrm{mL})(\mathrm{p}=0.942)$ and lower HBsAg levels (HBsAg-QT <100 000 mIU/mL) (p = 0.089) (Table 2).

\section{Correlation and agreement between $\mathrm{HBsAg}-\mathrm{HQ}$ and $\mathrm{HBsAg}-\mathrm{QT}$}

Independent of the serum $\mathrm{HBeAg}$ state and the $\mathrm{HBsAg}$ levels, the serum HBsAg-HQ had a significantly positive correlation with HBsAg-QT $(\mathrm{r}=0.955$; $\mathrm{p}=0.000)$ (Fig. 3A, Table 3). The linear regression analysis showed that HBsAg-HQ = $0.892+0.866 \times$ HBsAg-QT $(\mathrm{t}=53.087$; $\mathrm{p}=0.000)$. The Bland-Altman analysis showed that, compared to the serum HBsAg-QT levels, the serum HBsAgHQ levels had an upward bias of $0.04 \log _{10} \mathrm{mIU} / \mathrm{mL}$ with a $95 \%$ limit of agreement (LOA) of -0.61 to $0.69 \mathrm{mIU} / \mathrm{mL}$. The disagreement rates of $\leq 95 \%$ LOA and $\geq 95 \%$ LOA were $0.73 \%(2 / 275)$ and $2.91 \%(8 / 275)$, respectively, and that the

Table 1. Clinical characteristics of the patients according to their serum HBeAg state

\begin{tabular}{|c|c|c|c|c|}
\hline Characteristics & HBeAg-positive $(n=147)$ & HBeAg-negative $(n=128)$ & $\mathrm{x}^{2 \mathrm{a} / \mathrm{t}^{\mathrm{b}}}$ & p-value* \\
\hline Gender (male:female) & $93: 54$ & $87: 41$ & 0.478 & $0.490^{\mathrm{a}}$ \\
\hline Age [mean \pm SD (range)], [years] & $35.48 \pm 11.29(15-72)$ & $43.88 \pm 12.51(19-78)$ & 5.851 & $0.000^{b}$ \\
\hline Serum ALT [mean \pm SD (range)], $\times \cup L N^{\#}$ & $3.22 \pm 6.34(0.25-37.85)$ & $3.18 \pm 5.31(0.18-30.45)$ & 0.067 & $0.947^{b}$ \\
\hline Serum HBsAg-HQ $\left[\right.$ mean $\pm \mathrm{SD}$ (range)], $\left[\log _{10} \mathrm{mIU} / \mathrm{mL}\right]$ & $6.932 \pm 0.764(4.724-8.176)$ & $5.830 \pm 0.930(1.906-7.101)$ & 10.647 & $0.000^{b}$ \\
\hline Serum HBsAg-QT [mean \pm SD (range)], $\left[\log _{10} \mathrm{mIU} / \mathrm{mL}\right]$ & $6.915 \pm 0.856(4.375-8.097)$ & $5.773 \pm 1.053(1.778-7.226)$ & 9.777 & $0.000^{b}$ \\
\hline Serum HBV DNA [median (range)], [ $\left.\log _{10} I \mathrm{IU} / \mathrm{mL}\right]$ & $6.498 \pm 1.554$ (UD ->7.699) & $3.901 \pm 1.380($ UD ->7.644) & 14.557 & $0.000^{b}$ \\
\hline Pathological grade (G1:G2:G3) & $75: 33: 39$ & $84: 22: 22$ & 6.164 & $0.046^{\mathrm{a}}$ \\
\hline Pathological grade (S1:S2:S3:S4) & $56: 38: 21: 32$ & $58: 28: 21: 21$ & 2.533 & $0.469^{\mathrm{a}}$ \\
\hline
\end{tabular}

\# ULN - upper limit of normal $=40 \mathrm{IU} / \mathrm{L} ;{ }^{*} \mathrm{HBeAg}$-positive vs HBeAg-negative; ${ }^{\mathrm{a}} \chi^{2}$ test; ${ }^{\mathrm{b}}$ independent samples t-test. 

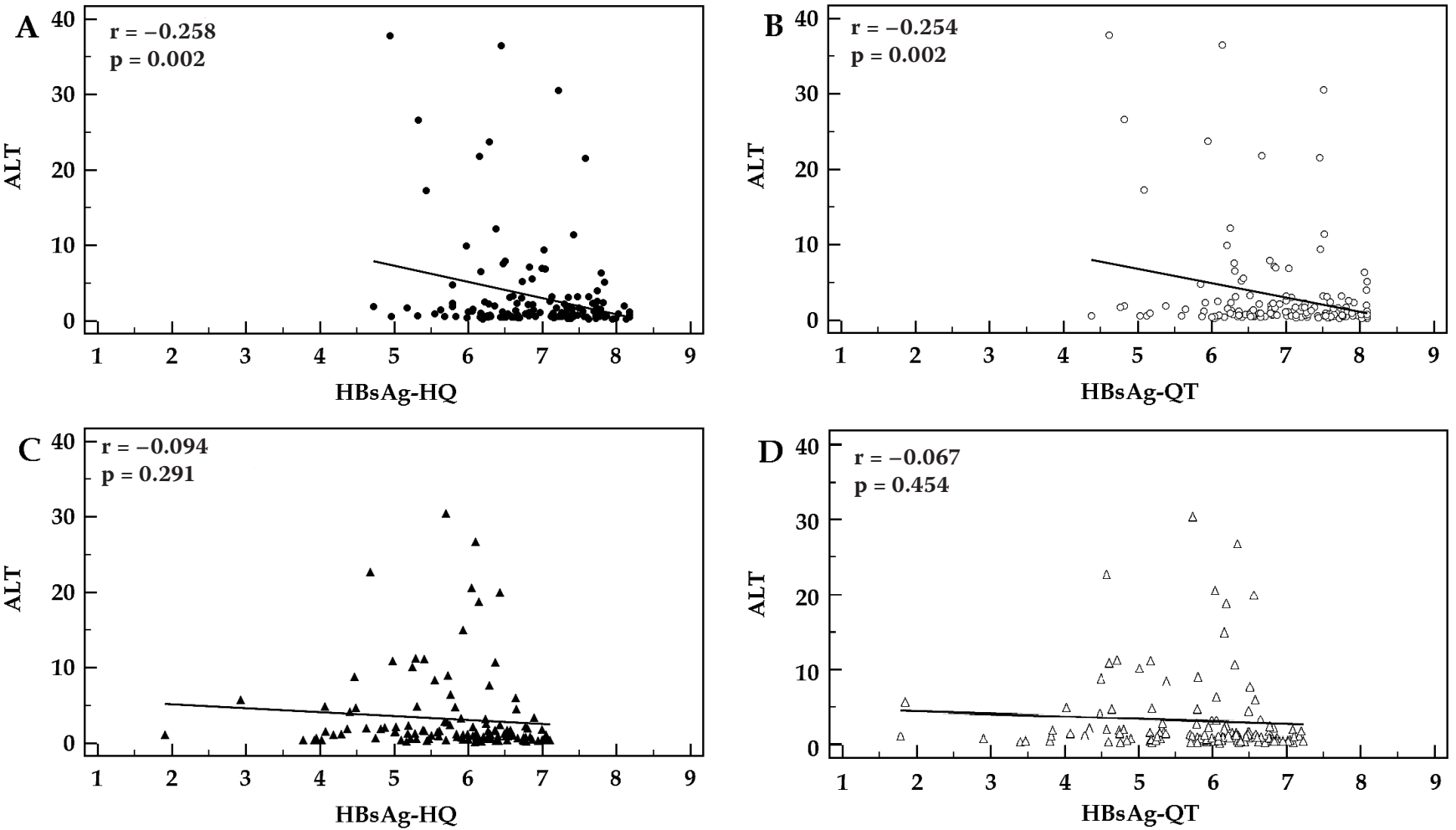

Fig. 1. Correlations of the serum HBsAg-HQ and HBsAg-QT with serum ALT in HBeAg-positive (A, B) and HBeAg-negative (C, D) patients
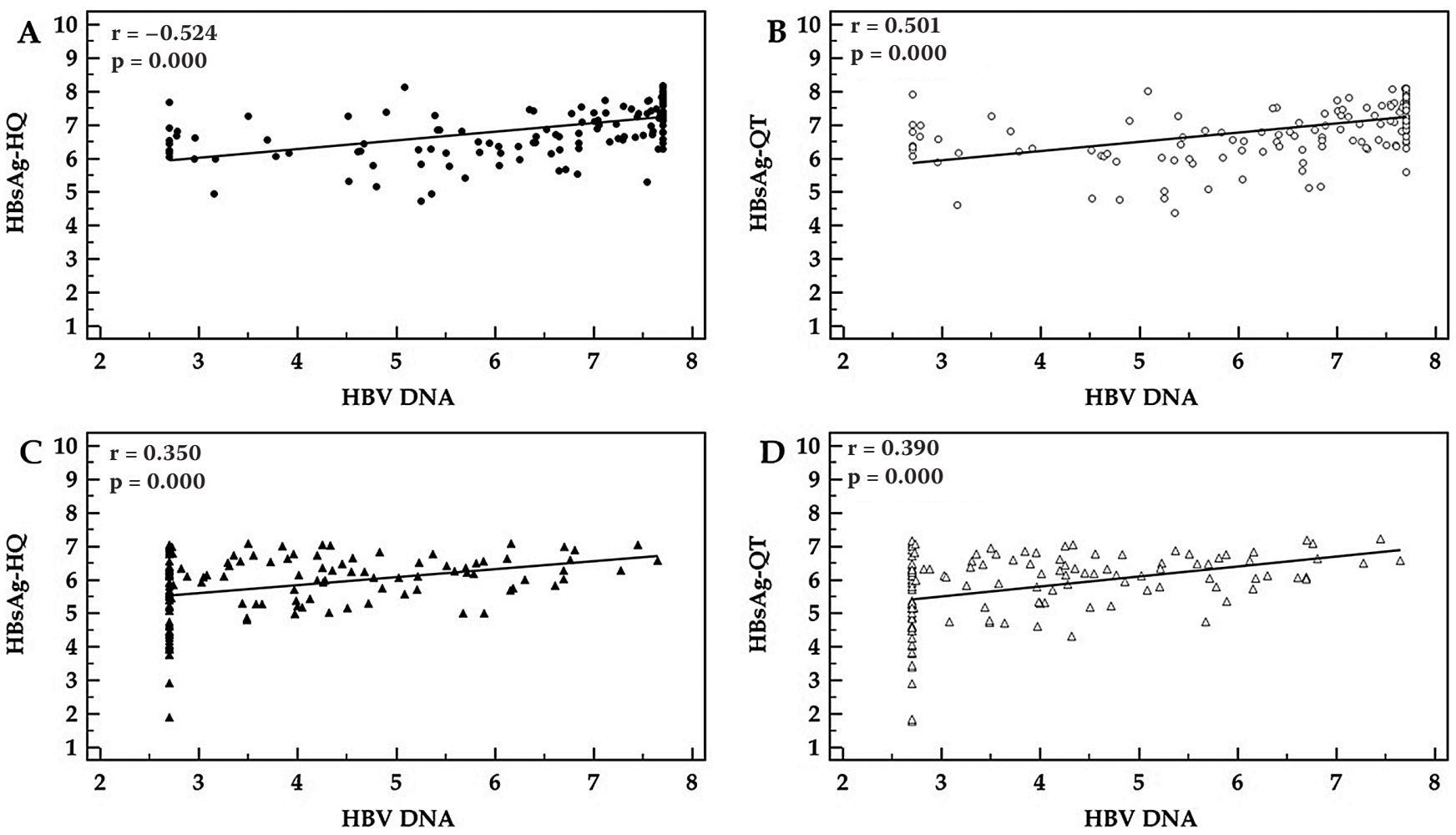

Fig. 2. Correlations of the serum $H B s A g-H Q$ and $H B s A g-Q T$ with serum HBV DNA in HBeAg-positive (A, B) and HBeAg-negative (C, D) patients

overall disagreement rate was $3.64 \%(10 / 275)$ between the serum HBsAg-HQ and HBsAg-QT (Fig. 3B, Table 3).

In the $\mathrm{HBeAg}$-positive patients, the serum $\mathrm{HBsAg}-\mathrm{HQ}$ had a significantly positive correlation with HBsAg-QT $(\mathrm{r}=0.913 ; \mathrm{p}=0.000)$ (Fig. $1 \mathrm{C}$, Table 3), and HBsAg$\mathrm{HQ}=1.296+0.815 \times$ HBsAg-QT $(\mathrm{t}=26.929 ; \mathrm{p}=0.000)$. The overall disagreement rate was $2.72 \%$ (4/147) between the serum HBsAg-HQ and HBsAg-QT (Fig. 1D, Table 3). 
Table 2. Comparison between the serum HBsAg-HQ and HBsAg-QT levels

\begin{tabular}{|l|c|c|c|c|c|}
\multicolumn{1}{|c|}{ Study population } & $\mathrm{N}$ & HBsAg-HQ $( \pm \mathrm{SD})$ & HBsAg-QT $( \pm \mathrm{SD})$ & $\mathrm{t}$-test & $\mathrm{p}$-value \\
\hline Overall & 275 & $6.419 \pm 1.007$ & $6.383 \pm 1.109$ & 0.397 & 0.691 \\
\hline HBeAg-positive & 147 & $6.932 \pm 0.764$ & $6.915 \pm 0.856$ & 0.185 & 0.853 \\
\hline HBeAg-negative & 128 & $5.830 \pm 0.930$ & $5.773 \pm 1.053$ & 0.459 & 0.647 \\
\hline HBsAg-QT $\geq 5.000 \log _{10} \mathrm{mlU} / \mathrm{mL}$ & 244 & $6.655 \pm 0.752$ & $6.660 \pm 0.790$ & 0.072 & 0.942 \\
\hline HBsAg-QT $<5.000 \log _{10} \mathrm{mlU} / \mathrm{mL}$ & 31 & $4.564 \pm 0.823$ & $4.206 \pm 0.806$ & 1.732 & 0.089 \\
\hline
\end{tabular}

The measurement units for $\mathrm{HBsAg}-\mathrm{HQ}$ and $\mathrm{HBsAg}-\mathrm{QT}$ were both $\log _{10} \mathrm{mlU} / \mathrm{mL}$.
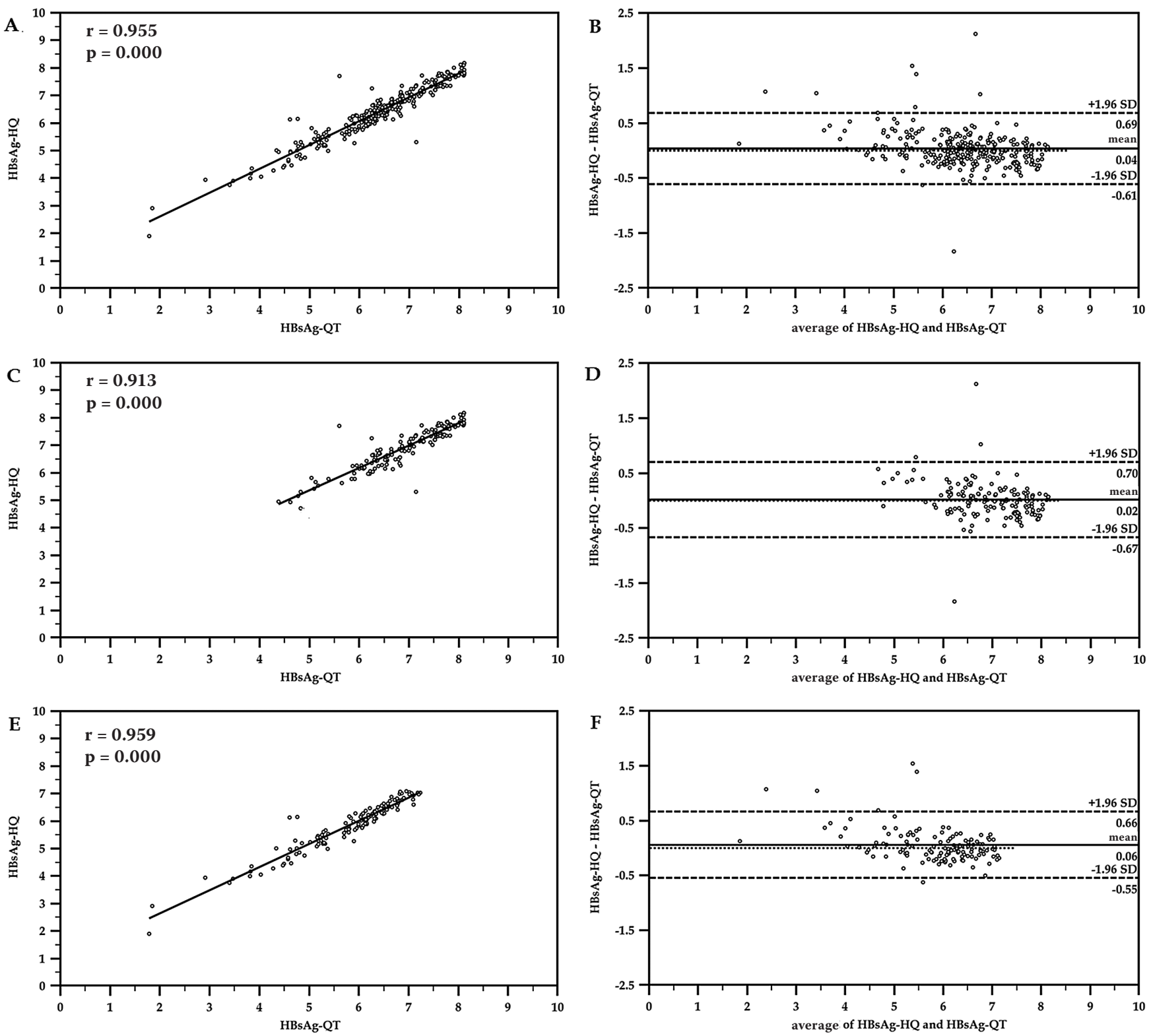

Fig. 3. Correlation and agreement between the serum HBsAg-HQ and HBsAg-QT

The measurement units of $\mathrm{HBs} A g-\mathrm{HQ}$ and $\mathrm{HBsAg}-\mathrm{QT}$ were both $\log _{10} \mathrm{mlU} / \mathrm{mL}$. A, C and E show the scatter diagrams of the correlation between serum $\mathrm{HBs} A g-\mathrm{HQ}$ and $\mathrm{HBsAg}$-QT in the overall, HBeAg-positive and HBeAg-negative patients; B, D and F show the Bland-Altman plots of the agreement between the serum HBsAg-HQ and HBsAg-QT in the overall, HBeAg-positive and HBeAg-negative patients, in which the upper and lower horizontal solid lines represent the upper and lower limits of the $95 \%$ LOA, respectively, and the middle horizontal solid lines represent the average of the serum HBsAg-HQ and HBsAg-QT difference. The horizontal dotted lines represent an average value of 0 for the serum HBsAg-HQ and HBsAg-QT differences.

In $\mathrm{HBeAg-negative} \mathrm{patients,} \mathrm{the} \mathrm{serum} \mathrm{HBsAg-HQ}$ had a significantly positive correlation with $\mathrm{HBsAg-QT}$ $(\mathrm{r}=0.959 ; \mathrm{p}=0.000)$ (Fig. 1E, Table 3); HBsAg-HQ = 0.963
$+0.843 \times$ HBsAg-QT $(\mathrm{t}=37.740 ; \mathrm{p}=0.000)$. The overall disagreement rate was $4.69 \%(6 / 128)$ between serum HBsAg-HQ and HBsAg-QT (Fig. 1F, Table 3). 
Table 3. Pearson correlation and agreement between the serum $\mathrm{HBsAg}-\mathrm{HQ}$ and $\mathrm{HBs} \mathrm{Ag}-\mathrm{QT}$

\begin{tabular}{|c|c|c|c|c|c|c|c|c|}
\hline \multirow{2}{*}{ Study population } & \multirow{2}{*}{$\mathrm{N}$} & \multirow{2}{*}{$r$} & \multirow{2}{*}{$p$-value } & \multirow{2}{*}{ Bias } & \multirow{2}{*}{$95 \%$ LOA } & \multicolumn{3}{|c|}{ Inconsistency rate (\%) } \\
\hline & & & & & & $\leq 95 \%$ LOA & $\geq 95 \%$ LOA & Sum \\
\hline Overall & 275 & 0.955 & 0.000 & 0.04 & $-0.61-0.69$ & $2 / 275(0.73)$ & $8 / 275(2.91)$ & $10 / 275(3.64)$ \\
\hline HBeAg-positive & 147 & 0.913 & 0.000 & 0.02 & $-0.67-0.70$ & $2 / 147(0.68)$ & $3 / 147(2.04)$ & $4 / 147(2.72)$ \\
\hline HBeAg-negative & 128 & 0.959 & 0.000 & 0.06 & $-0.55-0.66$ & $1 / 128(0.78)$ & $5 / 128(3.91)$ & $6 / 128(4.69)$ \\
\hline $\mathrm{HBsAg}-\mathrm{QT} \geq 5.000$ & 244 & 0.929 & 0.000 & -0.01 & $-0.58-0.57$ & $2 / 244(0.82)$ & $4 / 244(0.16)$ & $6 / 244(0.25)$ \\
\hline HBsAg-QT $<5.000$ & 31 & 0.861 & 0.000 & 0.36 & $-0.49-1.20$ & $0 / 31(0.00)$ & 2/31(6.45) & $2 / 31(6.45)$ \\
\hline
\end{tabular}

The measurement units for $\mathrm{HBsAg}-\mathrm{HQ}$ and $\mathrm{HBs} A g-\mathrm{QT}$ were both $\log _{10} \mathrm{mlU} / \mathrm{mL}$; bias - the average of serum HBsAg-HQ and HBsAg-QT differences; LOA - limit of agreement.
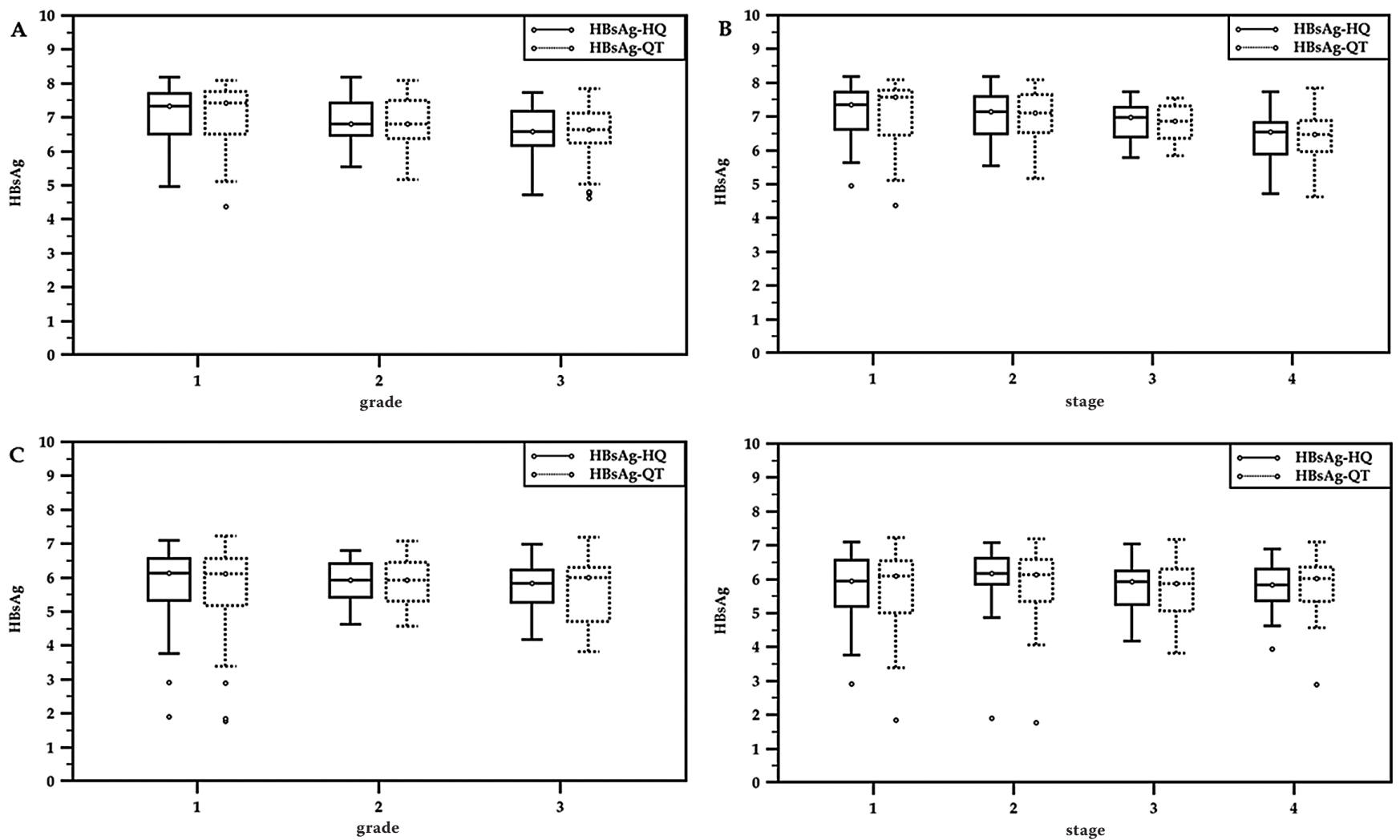

Fig. 4. Correlation of the serum $\mathrm{HBsAg}-\mathrm{HQ}$ and $\mathrm{HBsAg}-\mathrm{QT}$ levels with the liver tissue pathological grade and stage

The measurement units of HBsAg-HQ and HBsAg-QT were both $\log _{10} \mathrm{mIU} / \mathrm{mL}$. The box-plots represent the serum distributions of HBsAg-HQ and HBsAgQT in different pathological grades and stages in the HBeAg-positive (A, B) and HBeAg-negative patients (C, D), in which the top and bottom of the box indicates the upper and lower quartile, and the horizontal line in the box indicates the median. The upper and lower horizontal lines outside the box indicate the $95 \%$ quintile, and the circle indicates the extreme value.

In patients with higher $\mathrm{HBsAg}$ levels (HBsAgQT $\geq 100000 \mathrm{mIU} / \mathrm{mL}$ ), the serum HBsAg-HQ had a significantly positive correlation with HBsAg-QT ( $\mathrm{r}=0.929$; $\mathrm{p}=0.000$ ) (Table 3), such that HBsAg-HQ $=0.762+$ $0.885 \times$ HBsAg-QT $(\mathrm{t}=39.150 ; \mathrm{p}=0.000)$. The overall disagreement rate was $0.25 \%(6 / 244)$ between the serum HBsAg-HQ and HBsAg-QT levels (Table 3). In patients with lower HBsAg levels (HBsAg-QT <100 000 mIU/mL), the serum HBsAg-HQ had a significantly positive correlation with HBsAg-QT $(\mathrm{r}=0.861 ; \mathrm{p}=0.000)$ (Table 3), with HBsAg-HQ = $0.869+0.879 \times \mathrm{HBsAg-QT}(\mathrm{t}=9.098$; $\mathrm{p}=0.000)$. The overall disagreement rate was $6.45 \%(2 / 31)$ between the serum HBsAg-HQ and HBsAg-QT (Table 3).

\section{Correlation of HBsAg-HQ and HBsAg-QT with pathological grade and stage}

In $\mathrm{HBeAg}$-positive patients, the serum HBsAg-HQ and HBsAg-QT were significantly negatively correlated with the pathological grade $\left(r_{s}=-0.298 ; p=0.000\right.$ and $r_{s}=-0.320$; $\mathrm{p}=0.000$, respectively) and stage $\left(\mathrm{r}_{\mathrm{s}}=-0.366 ; \mathrm{p}=0.000\right.$ and $r_{s}=-0.373 ; p=0.000$, respectively) (Fig. 4A,B). In $\mathrm{HBeAg}$-negative patients, the serum HBsAg-HQ and HBsAg-QT levels were not significantly correlated with the pathological grade $\left(r_{\mathrm{s}}=-0.127 ; \mathrm{p}=0.155\right.$ and $\mathrm{r}_{\mathrm{s}}=-0.073$; $\mathrm{p}=0.411$, respectively) and stage $\left(\mathrm{r}_{\mathrm{s}}=-0.045 ; \mathrm{p}=0.615\right.$ and $r_{s}=-0.011 ; p=0.903$, respectively) (Fig. 4 C,D). 


\section{Performance of $\mathrm{HBsAg}-\mathrm{HQ}$ and $\mathrm{HBsAg}-\mathrm{QT}$ in predicting pathological states}

In $\mathrm{HBeAg}$-positive patients, all AUCs of the serum HBsAg-HQ and HBsAg-QT for predicting the pathological grades $\geq \mathrm{G} 2$ and $\geq \mathrm{G} 3$, and stages $\geq \mathrm{S} 2, \geq \mathrm{S} 3$ and $\geq \mathrm{S} 4$ were significantly greater than the area under the diagonal reference line (all $\mathrm{p}<0.01$ ). Of these, only the AUCs of serum HBsAg-HQ and HBsAg-QT for predicting pathological stage $\geq S 3$ and $\geq S 4$ were $>0.70$ (Table 4 , Fig. 5). In the $\mathrm{HBeAg}$-negative patients, all the AUCs of serum HBsAg$\mathrm{HQ}$ and $\mathrm{HBs} A g-\mathrm{QT}$ for predicting pathological grades $\geq \mathrm{G} 2$ and $\geq \mathrm{G} 3$, and stages $\geq \mathrm{S} 2, \geq \mathrm{S} 3$ and $\geq \mathrm{S} 4$ were not significantly greater than the area under diagonal reference line (all p > 0.05) (Table 4).

In $\mathrm{HBeAg}$-positive patients there were no significant differences for predicting all the same pathological states (all p > 0.05) between the AUCs of the serum HBsAg-HQ and HBsAg-QT (Table 4). In the HBeAg-negative patients, there were no significant differences for predicting the same pathological states except for predicting the pathological stage $\geq \mathrm{S} 4$ between the AUCs of serum HBsAg-HQ and HBsAg-QT ( $p=0.046$ for predicting the pathological stage $\geq S 4$, $\mathrm{p}>0.05$ for predicting the other pathological states) (Table 4).

The optimal cut-offs of serum HBsAg-HQ and HBsAg-QT for predicting a pathological grade $\geq \mathrm{G} 3$ were $<2.244 \times 10^{7}$ $\mathrm{mIU} / \mathrm{mL}$ and $<3.589 \times 10^{7} \mathrm{mIU} / \mathrm{mL}$, respectively, and the corresponding sensitivity, specificity were $87.18 \%$ and $97.44 \%$, and $43.52 \%$ and $38.89 \%$, respectively. The optimal cut-offs of serum HBsAg-HQ and HBsAg-QT for predicting the pathological stage $\geq \mathrm{S} 4$ were $<7.328 \times 10^{6} \mathrm{mIU} / \mathrm{mL}$ and $<6.194 \times 10^{6} \mathrm{mIU} / \mathrm{mL}$, respectively, and the corresponding sensitivity, specificity were $81.25 \%$ and $75 \%$, and $64.35 \%$ and $67.83 \%$, respectively (Table 5 ).

Table 4. AUCs of serum HBsAg-HQ and HBsAg-QT for predicting the different liver tissue pathological states

\begin{tabular}{|c|c|c|c|c|c|c|c|c|c|c|c|}
\hline \multirow{2}{*}{$\begin{array}{l}\text { Pathological } \\
\text { states }\end{array}$} & \multirow{2}{*}{$\mathrm{HBsAg}$} & \multicolumn{5}{|c|}{ HBeAg-positive } & \multicolumn{5}{|c|}{ HBeAg-negative } \\
\hline & & AUC* & $\mathrm{SE}^{\#}$ & $Z \wedge$ & $\mathrm{p}$-value & $95 \% \mathrm{Cl}$ & AUC* & $\mathrm{SE}^{\#}$ & $Z^{\wedge}$ & $p$-value & $95 \% \mathrm{Cl}$ \\
\hline \multirow{2}{*}{$\geq \mathrm{G} 2$} & $\mathrm{HBsAg}-\mathrm{HQ}$ & $0.651^{a}$ & 0.046 & 3.290 & 0.001 & $0.568 \sim 0.727$ & $0.573^{f}$ & 0.051 & 1.425 & 0.154 & $0.482 \sim 0.660$ \\
\hline & HBsAg-QT & $0.670^{a}$ & 0.045 & 3.755 & 0.000 & $0.588 \sim 0.745$ & $0.547^{f}$ & 0.052 & 0.781 & 0.435 & $0.451 \sim 0.629$ \\
\hline \multirow{2}{*}{$\geq \mathrm{G} 3$} & $\mathrm{HBsAg}-\mathrm{HQ}$ & $0.686^{b}$ & 0.047 & 3.957 & 0.000 & $0.604 \sim 0.760$ & $0.584^{9}$ & 0.064 & 1.317 & 0.188 & $0.493 \sim 0.671$ \\
\hline & HBsAg-QT & $0.684^{b}$ & 0.046 & 4.038 & 0.000 & $0.602 \sim 0.758$ & $0.558^{9}$ & 0.068 & 0.778 & 0.437 & $0.463 \sim 0.641$ \\
\hline \multirow{2}{*}{$\geq S 2$} & $\mathrm{HBsAg}-\mathrm{HQ}$ & $0.659^{c}$ & 0.049 & 3.266 & 0.001 & $0.576 \sim 0.735$ & $0.492^{h}$ & 0.054 & 0.145 & 0.885 & $0.402 \sim 0.582$ \\
\hline & $\mathrm{HBsAg-QT}$ & $0.660^{c}$ & 0.050 & 3.213 & 0.001 & $0.577 \sim 0.736$ & $0.514^{h}$ & 0.053 & 0.156 & 0.876 & $0.418 \sim 0.598$ \\
\hline \multirow{2}{*}{$\geq S 3$} & $\mathrm{HBsAg}-\mathrm{HQ}$ & $0.712^{d}$ & 0.042 & 5.045 & 0.000 & $0.632 \sim 0.784$ & $0.572^{i}$ & 0.052 & 1.391 & 0.164 & $0.481 \sim 0.659$ \\
\hline & HBsAg-QT & $0.720^{d}$ & 0.041 & 5.327 & 0.000 & $0.640 \sim 0.791$ & $0.540^{i}$ & 0.053 & 0.645 & 0.519 & $0.444 \sim 0.623$ \\
\hline \multirow{2}{*}{$\geq S 4$} & $\mathrm{HBsAg}-\mathrm{HQ}$ & $0.739^{e}$ & 0.046 & 5.159 & 0.000 & $0.660 \sim 0.808$ & $0.552^{j}$ & 0.064 & 0.810 & 0.418 & $0.461 \sim 0.640$ \\
\hline & HBsAg-QT & $0.745^{e}$ & 0.045 & 5.476 & 0.000 & $0.666 \sim 0.813$ & $0.508^{j}$ & 0.065 & 0.058 & 0.954 & $0.414 \sim 0.593$ \\
\hline
\end{tabular}

95\% Cl - 95\% confidence interval; * AUC - area under the ROC curve; \# SE - standard error; Z^ - independent samples DeLong non-parametric test; ${ }^{a-j}$ paired-samples DeLong non-parametric test; ${ }^{a} Z=1.005, p=0.315 ;{ }^{b} Z=0.071, p=0.943 ;{ }^{c} Z=0.034, p=0.973 ;{ }^{d} Z=0.391, p=0.696 ;{ }^{e} Z=0.238, p=0.812 ;$ ${ }^{f} Z=1.511, p=0.131 ;{ }^{g} Z=1.131, p=0.258 ;{ }^{h} Z=0.211, p=0.833 ;{ }^{i} Z=1.826, p=0.068 ;{ }^{j} Z=1.992, p=0.046$

Table 5. Optimal cut-offs of serum HBsAg-HQ and HBsAg-QT for predicting different pathological states and the corresponding diagnostic parameters in $\mathrm{HBeAg}$-positive patients

\begin{tabular}{|c|c|c|c|c|c|c|c|c|}
\hline Pathological states & $\mathrm{HBsAg}$ & Cut-off & SEN (\%) & SPE (\%) & $\mathrm{YI}$ & PPV (\%) & NPV (\%) & $\mathrm{ACC}$ \\
\hline \multirow{2}{*}{$\geq \mathrm{G} 2$} & $\mathrm{HBsAg}-\mathrm{HQ}$ & $<7.216$ & 73.61 & 58.67 & 0.323 & 63.1 & 69.8 & 0.329 \\
\hline & HBsAg-QT & $<7.555$ & 88.89 & 46.67 & 0.356 & 61.5 & 81.4 & 0.429 \\
\hline \multirow{2}{*}{$\geq \mathrm{G} 3$} & $\mathrm{HBsAg}-\mathrm{HQ}$ & $<7.351$ & 87.18 & 43.52 & 0.307 & 35.8 & 90.4 & 0.262 \\
\hline & HBsAg-QT & $<7.555$ & 97.44 & 38.89 & 0.363 & 36.5 & 97.7 & 0.342 \\
\hline \multirow{2}{*}{$\geq S 2$} & $\mathrm{HBsAg}-\mathrm{HQ}$ & $<7.622$ & 89.01 & 42.86 & 0.319 & 71.7 & 70.6 & 0.423 \\
\hline & HBsAg-QT & $<7.555$ & 84.62 & 51.79 & 0.364 & 74.0 & 67.4 & 0.414 \\
\hline \multirow{2}{*}{$\geq \mathrm{S} 3$} & $\mathrm{HBsAg}-\mathrm{HQ}$ & $<7.315$ & 86.79 & 53.19 & 0.400 & 51.1 & 87.7 & 0.388 \\
\hline & HBsAg-QT & $<7.555$ & 98.11 & 44.68 & 0.428 & 50.0 & 97.7 & 0.477 \\
\hline \multirow{2}{*}{$\geq S 4$} & $\mathrm{HBsAg}-\mathrm{HQ}$ & $<6.865$ & 81.25 & 64.35 & 0.456 & 38.8 & 92.5 & 0.313 \\
\hline & HBsAg-QT & $<6.792$ & 75.00 & 67.83 & 0.428 & 39.3 & 90.7 & 0.300 \\
\hline
\end{tabular}

The measurement units of HBsAg-HQ and HBsAg-QT were both $\log _{10} \mathrm{mIU} / \mathrm{mL}$; SEN - sensitivity; SPE - specificity; YI - Youden index; PPV - positive predictive value; NPV - negative predictive value; ACC - accuracy. 

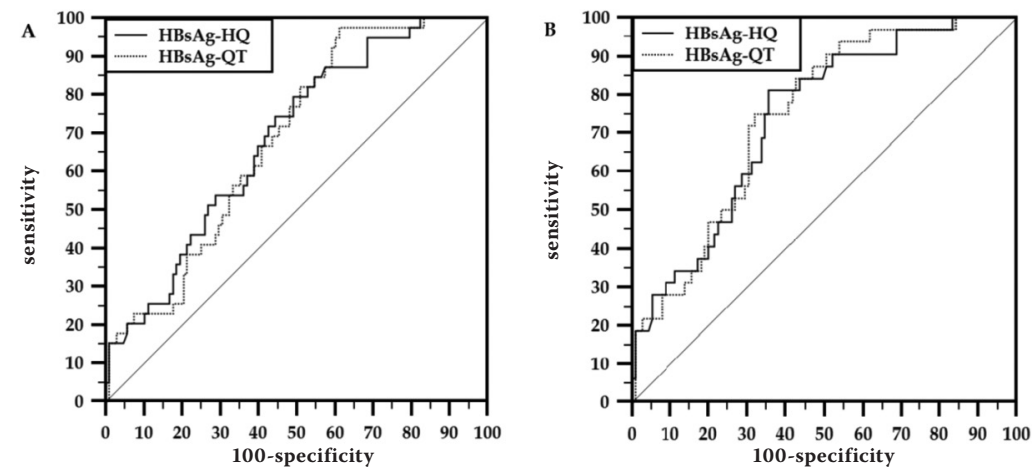

Fig. 5. ROC curves of serum $\mathrm{HBs} A g-\mathrm{HQ}$ and $\mathrm{HBs} A g-\mathrm{QT}$ for predicting a pathological grade $\geq \mathrm{G} 3$ and stage $\geq \mathrm{S} 4$ in HBeAg-positive patients

\section{Discussion}

Choi et al. confirmed that the qualitative results of serum HBsAg-HQhighlyagreed with those of the serum HBsAg-QT, with a concordance rate of $99.8 \%(\mathrm{k}=1.00 ; 95 \% \mathrm{CI}$, 0.99-1.00). Of the 315 HBsAg-QT-positive samples, 314 were $\mathrm{HBs} A g-\mathrm{HQ}$-positive. Of the $685 \mathrm{HBsAg-QT-negative}$ samples, 684 were HBsAg-HQ-negative. ${ }^{16}$ Recently, Yang et al. evaluated and compared the agreement of the qualitative and quantitative results of serum $\mathrm{HBsAg-HQ}$ with $\mathrm{HB}$ sAg-QT and HBsAg-EII. ${ }^{17}$ The results showed that of the 2,043 samples tested, 1,844 samples gave negative results for both HBsAg-HQ and HBsAg-QT, and 172 samples yielded positive results for both HBsAg-HQ and HBsAg-QT. Of the remaining 27 samples that had inconsistent $\mathrm{HBsAg}$ results, 3 were $\mathrm{HBsAg-QT-positive} \mathrm{and} 24$ were $\mathrm{HBsAg-}$ -HQ-positive. Among these, none of the $3 \mathrm{HBsAg-QT-}$ -positive samples were subsequently confirmed to be positive. Twenty of the $24 \mathrm{HBs} A g-\mathrm{HQ}$-positive samples were confirmed to be positive, 3 were confirmed to be negative and 1 gave an indeterminate result and therefore was excluded from the specificity calculation for $\mathrm{HBs} A g-\mathrm{HQ}$. The specificity was $99.84 \%$ for HBsAg-HQ and $99.84 \%$ for HBsAg-QT. Yang et al. also found that, of the 112 tested samples, HBsAg-HQ displayed an excellent correlation with both HBsAg-QT and HBsAg-EII ( $\mathrm{r}=0.985$ and $r=0.990)$; the Bland-Altman analyses demonstrated that, compared to HBsAg-QT and HBsAg-EII, HBsAg-HQ had an upward bias of $0.19 \log _{10} \mathrm{IU} / \mathrm{mL}$ with a $95 \% \mathrm{LOA}$ of -0.01 to $0.39 \log _{10} \mathrm{mIU} / \mathrm{mL}$ and $0.07 \log _{10} \mathrm{IU} / \mathrm{mL}$ with a $95 \%$ LOA of -0.12 to $0.25 \log _{10} \mathrm{mIU} / \mathrm{mL}$, respectively. ${ }^{17}$

In this study, the serum HBsAg-HQ was significantly correlated with HBsAg-QT. The Bland-Altman analyses showed that, compared to the serum HBsAg-QT, the HBsAg-HQ had a slight bias of $0.04 \log _{10} \mathrm{mIU} / \mathrm{mL}$ with a $95 \% \mathrm{LOA}$ of -0.61 to $0.69 \log _{10} \mathrm{mIU} / \mathrm{mL}$; the overall disagreement rate was $3.64 \%$. Further analyses of the grouping according to the $\mathrm{HBeAg}$ state (HBeAg-positive and $\mathrm{HBeAg}$-negative) and the HBsAg levels (higher HBsAg levels (HBsAg-QT $\geq 100000$ $\mathrm{mIU} / \mathrm{mL}$ ) and lower HBsAg levels (HBsAg-QT < 100000 $\mathrm{mIU} / \mathrm{mL})$ ) also showed similar results. This further demonstrated that the serum HBsAg-HQ levels were highly correlated and highly agreed with HBsAg-QT.
Seto et al. comparatively investigated the changes in the serum HBsAg-HQ and HBsAg-EII in different phases in the natural history of chronic HBV infection. ${ }^{18}$ The changes in the serum HBsAg-HQ in different phases were consistent with previous research based on the same criterion for the division of the natural history of chronic HBV infection. ${ }^{5,6,21-23}$ Unexpectedly, the serum HBsAg-HQ levels were significantly higher than the HBsAg-EII levels in either the immune tolerance or the activation phase of the $\mathrm{HBeAg}$-positive patients. However, the serum HBsAg-HQ levels were similar to the HBsAg-EII levels in either the immune escape or control phase of the HBeAg-negative patients. However, the reason why the serum HBsAg-HQ levels in HBeAg-positive patients were significantly higher than HBsAg-E levels is not clear. The investigators speculated that this could possibly be due to the enhanced detection of minor viral populations with "a" determinant mutations in patients with higher viral loads. However, Yang et al. reported that the $S$ gene mutations within the "a" determinant, such as T126A, T126S, Q129H, Q129R, T140S, and G145E, did not affect the correlation and agreement observed between the serum HBsAg-HQ and HBsAg-QT and HBsAg-EII. ${ }^{17}$

In this study, regardless of the serum HBeAg state and HBsAg levels, the difference between the serum HBsAgHQ and HBsAg-QT levels was not significant. Further analyses of the grouping according to the $\mathrm{HBeAg}$ state and HBsAg levels also showed similar results. Our results agreed with the study by Yang et al. but failed to find a serum HBsAg-HQ level that was not significantly higher than HBsAg-QT. ${ }^{17}$ This result was not consistent with the findings of a previous study conducted by Seto et al. ${ }^{18}$

For the cause-specific indexes, several studies have shown that serum HBsAg and HBV DNA in HBeAg-positive patients and HBV DNA but HBsAg in HBeAg-negative patients are valuable in predicting liver tissue pathological states. ${ }^{7,24-29}$ However, the predicable optimal pathological state of serum HBsAg and HBVDNA in the HBeAgpositive patients was not consistent between the different studies, ${ }^{7,24-27}$ although for the HBV DNA in the HBeAgnegative patients, there was an agreement in the pathological grade $\geq \mathrm{G} 2$ and stage $\geq \mathrm{S} 2$. $^{28,29}$ The results of this study were consistent with the findings by Cheng et al. and Jia 
et al., but not those of Martinot-Peignoux et al., Xun et al. and Seto et al. ${ }^{7,24-27}$ Furthermore, we did not observe significant differences in the AUCs for predicting the same liver tissue pathological states between the serum HBsAg-HQ and HBsAg-QT in the HBeAg-positive patients. This study further demonstrated that, in the HBeAg-positive patients, serum HBsAs for predicting the liver tissue pathological states was valuable. Importantly, the efficacies of serum HBsAg-HQ for predicting the liver tissue pathological states were highly consistent with those of HBsAg-QT.

The results of this study showed that, in $\mathrm{HBeAg}$-positive patients, the optimal cut-off of serum HBsAg-HQ for predicting a pathological grade $\geq$ G3 was $<7.351 \log _{10} \mathrm{mIU} / \mathrm{mL}$ $\left(2.244 \times 10^{7} \mathrm{mIU} / \mathrm{mL}\right)$, with a difference of $-0.204 \log _{10}$ $\mathrm{mIU} / \mathrm{mL}(-0.625 \mathrm{mIU} / \mathrm{mL})$ from HBsAg-QT. The corresponding sensitivity, specificity, and positive and negative predictive values were $87.18 \%, 43.52 \%, 35.8 \%$, and $90.4 \%$, respectively. The optimal cut-off of serum HBsAg-HQ for predicting a pathological stage $\geq S 4$ was $<6.865 \log _{10}$ $\mathrm{mIU} / \mathrm{mL}\left(7.328 \times 10^{6} \mathrm{mIU} / \mathrm{mL}\right)$, with a difference of 0.073 $\log _{10} \mathrm{mIU} / \mathrm{mL}(1.183 \mathrm{mIU} / \mathrm{mL})$ from HBsAg-QT. The corresponding sensitivity, specificity, and positive and negative predictive values were $81.25 \%, 64.35 \%, 38.8 \%$, and $92.5 \%$, respectively. This suggests that, in HBeAg-positive patients, the optimal cut-offs of serum HBsAg-HQ for predicting pathological grade $\geq \mathrm{G} 3$ and stage $\geq \mathrm{S} 4$ should be highly consistent with those of HBsAg-QT, and serum HBsAg-HQ and HBsAg-QT should be very valuable for predicting pathological grade $\geq \mathrm{G} 3$ and stage $\geq \mathrm{S} 4$.

In conclusion, this study further evaluated the agreement between the serum HBsAg-HQ and HBsAg-QT levels and comparatively investigated the effectiveness of serum $\mathrm{HBsAg-HQ}$ and HBsAg-QT in predicting the liver tissue pathological states of $\mathrm{CHB}$. The results showed that the serum HBsAg-HQ was highly correlated and agreed with the HBsAg-QT in both the HBeAg-positive and HBeAgnegative patients, regardless of whether they presented with higher or lower HBsAg levels. Furthermore, serum HBsAg-HQ and HBsAg-QT had good predictive efficacy on the pathological grade $\geq \mathrm{G} 3$ and stage $\geq \mathrm{S} 4$ in $\mathrm{HBeAg}$ positive patients, but did not have predictive efficacy on the pathological states in HBeAg-negative patients.

\section{References}

1. Deguchi M, Yamashita N, Kagita M, et al. Quantitation of hepatitis $B$ surface antigen by an automated chemiluminescent microparticle immunoassay. J Virol Methods. 2004;115:217-222. doi:10.1016/j. jviromet.2003.10.002

2. Wong GLH, Chan HLY. Use of quantitative hepatitis B surface antigen with hepatitis B virus DNA in clinical practice. Clin Liver Dis. 2013;2:8-10. doi:10.1002/cld.165

3. Zhou B, Liu M, Lv G, et al. Quantification of hepatitis B surface antigen and e antigen: Correlation between Elecsys and Architect assays. J Viral Hepat. 2013;20:422-429. doi:10.1111/jvh.12044

4. Park Y, Hong DJ, Shin S, et al. Performance evaluation of new automated hepatitis $B$ viral markers in the clinical laboratory: Two quantitative hepatitis B surface antigen assays and an HBV core-related antigen assay. Am J Clin Pathol. 2012;137:770-777. doi:10.1309/ AJCP8QDN7NAUXJFJ
5. Tan Z, Li M, Kuang X, et al. Clinical implications of hepatitis B surface antigen quantitation in the natural history of chronic hepatitis $B$ virus infection. J Clin Virol. 2014;59:228-234. doi:10.1016/j.jcv.2014.01.013

6. Wang L, Zou ZQ, Wang K, et al. Role of serum hepatitis B virus marker quantitation to differentiate natural history phases of HBV infection. Hepatol Int. 2016;10:133-138. doi:10.1007/s12072-015-9657-6

7. Martinot-Peignoux M, Carvalho-Filho R, Lapalus M, et al. Hepatitis $B$ surface antigen serum level is associated with fibrosis severity in treatment-naïve, e antigen-positive patients. J Hepatol. 2013;58: 1089-1095. doi:10.1016/j.jhep.2013.01.028

8. Goyal SK, Jain AK, Dixit VK, et al. HBsAg level as predictor of liver fibrosis in $\mathrm{HBeAg}$ positive patients with chronic hepatitis B virus infection. J Clin Exp Hepatol. 2015;5:213-220. doi:10.1016/j.jceh.2015.04.008

9. Moucari R, Marcellin P. Quantification of hepatitis B surface antigen: A new concept for the management of chronic hepatitis B. Liver Int. 2011;31(Suppl 1):122-128. doi:10.1111/j.1478-3231.2010.02390.x

10. Tseng TC, Liu CJ, Yang HC, et al. Serum hepatitis surface antigen levels help predict disease progression in patients with low hepatitis B virus loads. Hepatology. 2013;57:441-450. doi:10.1002/hep.26041

11. Matsubara N, Kusano $O$, Sugamata $Y$, et al. A novel hepatitis $B$ virus surface antigen immunoassay as sensitive ashepatitis $B$ virus nucleic acid testing in detecting early infection. Transfusion. 2009;49:585595. doi:10.1111/j.1537-2995.2008.02026.x

12. Seto WK, Tanaka Y, Wong DK, et al. Evidence of serologic activity in chronic hepatitis B after surface antigen (HBsAg) seroclearance documented by conventional HBsAg assay. Hepatol Int. 2013;7:98105. doi:10.1007/s12072-012-9354-7

13. Seto WK, Tanaka Y, Wong DK, et al. Longitudinal profiles of highly sensitive hepatitis B surface antigen levels: Re-evaluation of HBsAg seroclearance. Liver Int. 2016;36:642-650. doi:10.1111/liv.12980

14. Shinkai N, Matsuura K, Sugauchi F, et al. Application of a newly developed high-sensitivity HBsAg chemiluminescent enzyme immunoassay for hepatitis B patients with HBsAg seroclearance. J Clin Microbiol. 2013;51:3484-3491. doi:10.1128/JCM.00726-13

15. Duong LT, Coignard C. Evaluation of a new high sensitive, qualitative and quantitative Hepatitis B surface antigen assay. J Clin Virol. 2015;70(Suppl 1):S95.

16. Choi SJ, Park Y, Lee EY, et al. Performance evaluation of Lumipulse G1200 autoimmunoanalyzer for the detection of serum hepatitis B virus markers. J Clin Lab Anal. 2013;27:204-206. doi:10.1002/ jcla. 21584

17. Yang R, Song G, Guan W, et al. The Lumipulse G HBsAg-Quant assay for screening and quantification of the hepatitis $B$ surface antigen. J Virol Methods. 2016;228:39-47. doi:10.1016/j.jviromet.2015.11.016

18. Seto WK, Wong DK, Fung J, et al. Linearized hepatitis B surface antigen and hepatitis $B$ core-related antigen in the natural history of chronic hepatitis B. Clin Microbiol Infect. 2014;20:1173-1180. doi:10.1111/1469-0691.12739

19. Sarin SK, Kumar M, Lau GK, et al. Asian-Pacific clinical practice guidelines on the management of hepatitis B: A 2015 update. Hepatol Int. 2016;10:1-98. doi:10.1007/s12072-015-9675-4

20. Brunt EM. Grading and staging the histopathological lesions of chronic hepatitis: The Knodell histology activity index and beyond. Hepatology. 2000;31:241-246. doi:10.1002/hep.510310136

21. Cheng XD, Song LW, Fang LL, et al. Comparison of three luminescent immunoassays for hepatitis B virus surface antigen quantification during the natural history of chronic hepatitis B virus infection. Clin Vaccine Immunol. 2014;21:1521-1527. doi:10.1128/CVI.00529-14

22. Suh SJ, Bae SI, Kim JH, et al. Clinical implications of the titer of serum hepatitis B surface antigen during the natural history of hepatitis B virus infection. J Med Virol. 2014;86:117-123. doi:10.1002/jmv.23767

23. Zeng LY, Lian JS, Chen JY, et al. Hepatitis B surface antigen levels during natural history of chronic hepatitis B: A Chinese perspective study. World J Gastroenterol. 2014;20:9178-9184. doi:10.3748/wjg.v20. i27.9178

24. Cheng PN, Tsai HW, Chiu YC, et al. Clinical significance of serum HBsAg levels and association with liver histology in $\mathrm{HBeAg}$ positive chronic hepatitis B. J Clin Virol. 2013;57:323-330. doi:10.1016/j.jcv.2013.04.012

25. Jia W, Qi X, Ji YY, et al. Low serum hepatitis B surface antigen level predicts compensated cirrhosis caused by chronic hepatitis B in $\mathrm{HBeAg}$ positive patients in east China. Hepat Mon. 2015;15:e29183. doi: 10.5812/hepatmon.29183 
26. Xun $Y H$, Zang GQ, Guo JC, et al. Serum hepatitis B surface antigen quantification as a useful assessment for significant fibrosis in hepatitis B e antigen-positive hepatitis B virus carriers. J Gastroenterol Hepatol. 2013;28:1746-1755. doi:10.1111/jgh.12304

27. Seto WK, Wong DK, Fung J, et al. High hepatitis B surface antigen levels predict insignificant fibrosis in hepatitis $B$ e antigen positive chronic hepatitis B. PLoS One. 2012;7:e43087. doi:10.1371/journal. pone. 0043087
28. Alam S, Ahmad N, Mustafa G, et al. Evaluation of normal or minimally elevated alanine transaminase, age and DNA level in predicting liver histological changes in chronic hepatitis B. Liver Int. 2011;31:824-830. doi:10.1111/j.1478-3231.2011.02491.x

29. Croagh CMN, Bell SJ, Slavin J, et al. Increasing hepatitis B viral load is associated with risk of significant liver fibrosis in $\mathrm{HBeAg}$-negative but not HBeAg-positive chronic hepatitis B. Liver Int. 2010;30:11151122. doi:10.1111/j.1478-3231.2010.02267.x 